\title{
Assessment of Job Induced Stress and Self- Competency among the Newly Joined Staff Nurses Working in the Selected Hospital, West Bengal
}

\author{
Riya Khanam
}

Tutor, Priyamvada Birla Institute of Nursing, Kolkata

\begin{abstract}
Descriptive survey research was conducted to assess the job induced stress and self competency among the newly joined staff nurses in a government hospital, West Bengal with the objective to identify the level of job induced stress and level of self competency among newly joined staff nurses, to identify the relationship between job induced stress and self competency among the newly joined staff nurses, to identify the association between level of job induced stress and socio-demographic variables and level of self competency among newly joined staff nurses. The conceptual framework was based on the NIOSH model of job stress and health. Data were collected from 100 newly joined staff nurses by non-probability Convenience sampling technique with the help of standardized HSE job stress questionnaire and Professional Competency Self-Assessment Tool Adapted from Virginia Tech. Findings revealed that all of the newly joined staff nurses had below mean score of each area (demand- 2.15 controls- 2.17, support -2.32 relationship- 2.5, role- 2.55, and change 2.24) which indicated that they had experienced a very high-risk stress level. And Majority (77\%) newly joined staff nurses had experienced a moderate level of self competency. Statistically significant relationship $\mathrm{t}=9.922, \mathrm{p}<0.05$ was found between the level of job induced stress and self competency respectively. Statistically, a significant positive relation was found between job induced stress level and selected demographic variables like level of qualification, total family income, marital status, and place of living, and no significant association was found with age, job experience, and types of family. Statistically, a significant association was found between the level of self competency and selected demographic variables like level of qualification like the place of posting, marital status, and types of family, and no significant association was found with age, job experience, total family income, and place of living. Considering the findings, some recommendations were offered for future research.
\end{abstract}

Key words: Job induced stress, Self competency, newly joined staff nurses,

\section{INTRODUCTION}

Alharbi H, and Alshehry A (2019) conducted a descriptive cross sectional study to Examine perceived stress and coping behaviors among nurses in intensive care units in Saudi Arabia, and the influence of coping mechanisms on stress. Total 154 nurses were selected and the result was found that the majority of the respondents reported a moderate level of stress in the past month (87.0\%). [1]
II-Ok Kim (2014) conducted a crosssectional descriptive study on Relationship among Essentials of Fundamental Nursing Skills Performance, Stress from Work and Work Capability of New Clinical Nurses in Korea to identify stress from work experienced by new clinical nurses. The subjects were 224 new clinical nurses. The result was found that the highest frequency of new clinical nurses was vital sign measurement $(4.74, \pm .89)$ and the lowest frequency of performance was Basic CPR \& 
defibrillator application $(1.81, \pm .94)$. There were significant positive correlations between frequency and confidence of $\operatorname{EFNSP}(\mathrm{r}=.64, \mathrm{p}<.001)$, frequency and work capability $(\mathrm{r}=.34, \mathrm{p}<.001)$, and confidence of EFNSP and work capability $(\mathrm{r}=.48$, $\mathrm{p}<.001)$, but negative correlation stress from work and work capability ( $\mathrm{r}=-.17, \mathrm{p}=.009)$. General characteristics, stress from work, frequency and confidence in EFNSP and stress from work explain $25.1 \%$ of work capability. [2]

Mohamed G M, Abdelrazek F, Eldeen K.M, Elsayed M.N (2015) conducted a study among 30 head nurses to assess the relationship between job stress and head nurses job performance level and found that the highest percentage of head nurses have high job stress level especially for lack of organization support, material stressors, work satisfaction, in addition to achievement and promotion stressors, and work and education stressors, and poor job performance especially for leadership / supervisory dimensions followed by work dimensions. [3]

Salem A.B, Ali K.A,Taha A.H, Diab S.N (2020) conducted a study among 23 nurses to evaluate nurses knowledge, skill, behavior through self competency scale and found that $65 \%$ of nurses had high level of competency and $22 \%$ of nurse needed more medium level of competency and $13 \%$ of nurses had low level of competency.[4]

\section{Need of the study}

Godwin A, Alexander S. Laar, and Harrison S (2016) conducted a research on occupational stress and its management among nurses at st. dominic hospital, Akwatia, Ghan. The result was found that Majority $72(98.6 \%)$ of the nurses identified inadequate motivation, inadequate staffing levels $67(91.8 \%)$, handling a large number of patient's alone $61(83.6 \%)$, and lack of break period during shift $60(82.2 \%)$ as cause of occupational stress. Minority of the nurses acknowledged that, frequent night duty 24 (32.9\%), working with incompetent staff $29(39.7 \%)$ and inadequate delegation of responsibilities $29 \quad(39.7 \%)$ imposed stress on them. [5]

Hajbaghery, Khamechian M, and Masoodi A N (2012) conducted a study in Kashan, Iran, investigated the nurses' experiences and perceptions regarding the occupational stress. Data were collected through in-depth individual interviews with 19 nurses. Participants had at least two years of experience and no self-reported history of mental illness. The result of the study was found that job stress as a condition in which a nurse is under pressure so that the quality of care and the nurses' personal and family life is interrupted. Being under continuous pressure, low social dignity, and the manner of nurse managers were among the important sources of job stress. Providing appropriate logistics, improving the coordination within hospital subsystems, and improving the managers and nurses relationships may decrease the stressors in nursing profession. [6]

\section{Purpose of the study}

To assess the level of Job induced Stress and Self-competency of the newly joined staff nurses.

\section{Objective of Study}

1. To assess the level of Job induced Stress among newly joined Staff Nurses.

2. To determine the level of Selfcompetency among newly joined Staff Nurses.

3. To identify relationship between Job induced Stress and Self-competency.

4. To find out association between level of job induced Stress and selected Socio demographic variables.

5. To find out association between the level of self-competency and selected Socio demographic variables.

\section{Assumption}

The study assumes that

- Newly joined Staff Nurses may experience job induced stress.

- Job induced stress of Nursing personnel is measurable. 
Riya Khanam. Assessment of job induced stress and self-competency among the newly joined staff nurses working in the selected hospital, West Bengal.

- Self-competency of nursing personnel is measurable.

- Self-competency can be influenced by Job related Stress.

\section{Delimitation}

The study is delimited to

Who are willing to participate in the study.

\section{MATERIALS AND METHODS}

Research approach: Survey research approach.

Research design: Descriptive research design.

\section{Variables}

The variables in the present study are

\section{Research Variables}

- Job induced Stress.

- Self-competency.

\section{Demographic Variables}

Age, gender, qualification, months of experience, place of posting.

Settings for the study: IPGMER \& SSKM Hospital, Kolkata.

Population of the study: Newly joined staff nurses.

Sample: Newly joined staff nurses working in the selected government hospital.

Sample size: 100

Sampling technique: Convenience sampling technique.

Table 1 Data collection tool and techniques

\begin{tabular}{|l|l|l|l|}
\hline Tool No & Variables & Tools & Techniques \\
\hline Tool- I & $\begin{array}{l}\text { Demographi } \\
\text { c variables }\end{array}$ & $\begin{array}{l}\text { Semi structured } \\
\text { questionnaire }\end{array}$ & $\begin{array}{l}\text { Paper pencil } \\
\text { test }\end{array}$ \\
\hline Tool -II & $\begin{array}{l}\text { Job induced } \\
\text { stress }\end{array}$ & $\begin{array}{l}\text { HSE job stress } \\
\text { questionnaire }\end{array}$ & $\begin{array}{l}\text { Paper pencil } \\
\text { test }\end{array}$ \\
\hline Tool -III & $\begin{array}{l}\text { Self } \\
\text { competency }\end{array}$ & $\begin{array}{l}\text { Professional } \\
\text { competency self } \\
\text { assessment tool. }\end{array}$ & $\begin{array}{l}\text { Paper pencil } \\
\text { test }\end{array}$ \\
\hline
\end{tabular}

ANALYSIS OF DATA

Sections of the study

Section I Findings related to description of sample characteristics.
Table 2 frequency and percentage distribution of staff nurses according to sample characteristics, $n=100$

\begin{tabular}{|l|c|c|}
\hline Variables & Frequency & Percentage \\
\hline Age & 23 & $23 \%$ \\
\hline $20-22$ & 36 & $36 \%$ \\
\hline $23-25$ & 41 & $41 \%$ \\
\hline above 25 & Nil & - \\
\hline Sex & 100 & $100 \%$ \\
\hline Male & 33 & $33 \%$ \\
\hline Female & 39 & $39 \%$ \\
\hline Level of qualification & 28 & $28 \%$ \\
\hline GNM & 40 & $40 \%$ \\
\hline B.Sc. Nursing & 60 & $60 \%$ \\
\hline P.B.B.Sc. Nursing & Nil \\
\hline Marital Status & 54 & - \\
\hline Married & 46 & $54 \%$ \\
\hline Unmarried & \multicolumn{2}{|l}{} \\
\hline Nursing experience & \multicolumn{2}{|l|}{} \\
\hline 0- 4 months &
\end{tabular}

Table 3 Frequency and percentage distribution of staff nurses according to sample characteristics, $n=100$

\begin{tabular}{|c|l|l|}
\hline Variables & Frequency & Percentage \\
\hline Place of posting & & \\
\hline Medicine ward & 50 & $50 \%$ \\
\hline Surgical ward & 50 & $50 \%$ \\
\hline Place of Living & & \\
\hline Home & 43 & $43 \%$ \\
\hline Hostel & 33 & $33 \%$ \\
\hline PG & 24 & $24 \%$ \\
\hline Total Family Income & & \\
\hline$<40000 /-$ & 18 & $18 \%$ \\
\hline $40000 /-55000 /-$ & 57 & $57 \%$ \\
\hline$>55000 /-$ & 25 & $25 \%$ \\
\hline Types of Family & & $42 \%$ \\
\hline Joint & 42 & $58 \%$ \\
\hline Nuclear & 58 & \\
\hline
\end{tabular}

Section II Findings related to description of level of job induced stress

Table 4 Mean, Median and Standard deviation of job induced stress of staff nurses. $n=100$

\begin{tabular}{|l|l|l|l|l|}
\hline Variables & Range & Mean & Median & $\begin{array}{l}\text { Standard } \\
\text { Deviation }\end{array}$ \\
\hline $\begin{array}{l}\text { Job induced } \\
\text { stress }\end{array}$ & $35-175$ & 79.94 & 81 & 4.26 \\
\hline
\end{tabular}

Table 3 represented the percentile distribution of mean score for each area of Demand, Control, Support, Relationship, Role, and Change of newly joined staff nurses (taken 100 numbers of newly joined staff Nurses) in terms of level of job induced stress.

In this table the area 'demand' explored newly staff nurse's opinions on seven factors associated with work: deadlines, work tasks, intensity of work, speed of work tasks, breaks, duration, amount of work and competing demands. And the result revealed that the mean score 
Riya Khanam. Assessment of job induced stress and self-competency among the newly joined staff nurses working in the selected hospital, West Bengal.

in the area of 'demand' was 2.15 which very high risk within red zone. were below 20th percentile that indicated

Table 5 Percentile distribution of mean score for each standard of newly joined staff nurses in terms of level of job induced stress. $\mathbf{n}=100$

\begin{tabular}{|c|c|c|c|c|c|c|c|c|}
\hline \multirow[t]{2}{*}{ Area } & \multicolumn{2}{|c|}{$\begin{array}{l}\text { Red <20th percentile } \\
\text { Very High Risk }\end{array}$} & \multicolumn{2}{|c|}{$\begin{array}{c}\text { Yellow }>=20 \text { th } \&<50 \text { th } \\
\text { percentile } \\
\text { High Risk }\end{array}$} & \multicolumn{2}{|c|}{$\begin{array}{c}\text { Aqua }>=50 \text { th } \&<80 \text { th } \\
\text { percentile } \\
\text { Moderate risk }\end{array}$} & \multicolumn{2}{|c|}{$\begin{array}{c}\text { Green }>=80 \text { th percentile } \\
\text { Low risk }\end{array}$} \\
\hline & $\begin{array}{l}\text { Standard } \\
\text { (Avg. } \\
\text { score) }\end{array}$ & $\begin{array}{c}\text { Results } \\
\text { (Avg. score) }\end{array}$ & $\begin{array}{c}\text { standard } \\
\text { (Avg. score) }\end{array}$ & $\begin{array}{c}\text { Results } \\
\text { (Avg. score) }\end{array}$ & $\begin{array}{c}\text { standard } \\
\text { (Avg. score) }\end{array}$ & $\begin{array}{c}\text { Results } \\
\text { (Avg. score) }\end{array}$ & $\begin{array}{l}\text { standard } \\
\text { (Avg. score) }\end{array}$ & $\begin{array}{c}\text { Results } \\
\text { (Avg. score) }\end{array}$ \\
\hline Demand & $<2.93$ & 2.15 & $\begin{array}{c}>=2.9387 \& \\
<3.1024\end{array}$ & --- & $\begin{array}{c}>=3.1024 \& \\
<3.2937\end{array}$ & --- & $>=3.2937$ & --- \\
\hline Control & $<3.22$ & 2.17 & $\begin{aligned}> & =3.2240 \& \\
& <3.4741\end{aligned}$ & --- & $\begin{aligned}> & =3.4741 \& \\
& <3.7208\end{aligned}$ & --- & $>=3.7208$ & --- \\
\hline Support & $<3.27$ & 2.32 & $\begin{aligned}> & =3.2720 \& \\
& <3.4603\end{aligned}$ & --- & $\begin{aligned}> & =3.4603 \& \\
& <3.6500\end{aligned}$ & --- & $>=3.6500$ & --- \\
\hline $\begin{array}{l}\text { Relations } \\
\text { hip }\end{array}$ & $<3.61$ & 2.5 & $\begin{aligned}> & =3.6115 \& \\
& <3.8499\end{aligned}$ & --- & $\begin{aligned}> & =3.8499 \& \\
& <4.0381\end{aligned}$ & --- & $>=4.0381$ & --- \\
\hline Role & $<4.03$ & 2.55 & $\begin{aligned}> & =4.0356 \& \\
& <4.1803\end{aligned}$ & --- & $\begin{aligned}> & =4.1803 \& \\
& <4.3117\end{aligned}$ & --- & $>=4.3117$ & --- \\
\hline Change & $<2.79$ & 2.24 & $\begin{array}{c}>=2.7910 \& \\
<3.0428\end{array}$ & --- & $\begin{array}{c}>=3.0428 \& \\
\quad<3.2400\end{array}$ & --- & $>=3.2400$ & --- \\
\hline
\end{tabular}

(---) Doted lines indicated no result found within the HSE management Standards (stress risk assessment tool) range for the assessment of job induced stress among the newly joined staff nurses

The area 'control' consisted of six factors which inquired into how much influence a newly joined staff nurse had relating to their working time, how they work, what to work on, how to work, speed of work and when to have a break, and the result showed that total mean score of the newly joined staff nurses in the area of 'control' was 2.17 which was below 20th percentile that indicate very high risk within red zone.

The area 'support' explored that manager's provided support on a range of issueed such as encouragement, emotionally, discussions, problem solving and feedback, work colleagues, listening, respect assistance and help. The result showed that total mean score of the newly joined staff nurses in the area of 'support' was 2.32 which was below 20th percentile that indicated very high risk within red zone.

In the area of 'relationships' consisted of four factors which explored, strained relationships, bullying, friction between colleagues and harassment in working area of the newly joined staff nurses. In this table the result showed that the total mean score of the newly joined staff nurses in the area of 'relationship' was
2.50 which were below 20th percentile that indicated very high risk within red zone.

'Role' explored five factors including, understanding work aims, clear about goals and objectives, clear about duties, can get the job done and clear about what was expected of newly joined staff nurses, and the result showed that the total mean score of the newly joined staff nurses in the area of 'role' was 2.55 which was below 20th percentile that indicate very high risk within red zone.

'Change' consisted of three factors exploring issues such as how changes effected work parties, consultation about change and opportunities to discuss change, and the result showed that the total mean score of the newly joined staff nurses in the area of 'role' was 2.24 which was below 20th percentile that indicate very high risk within red zone.

Table 6 Mean, median and standard deviation of overall job induced stress score. $\mathrm{n}=\mathbf{1 0 0}$

\begin{tabular}{|l|c|c|c|}
\hline Percentile & Mean & Median & SD \\
\hline Demand & 17.2 & 17.5 & 2.1 \\
\hline Control & 13.03 & 13 & 1.5 \\
\hline Support & 20.93 & 20 & 2.19 \\
\hline Relationship & 10.01 & 10 & 1.45 \\
\hline Role & 12.46 & 13 & 1.45 \\
\hline Change & 6.73 & 7 & 1.52 \\
\hline
\end{tabular}

Table 6 represented the mean, median \& SD in each area of job induced 
stress. The mean score in the area of demand was 17.2, median 17.5 and SD 2.1. In the area of Control the mean score was 13.03, median 13 and SD 1.5. The mean score in the area of support was 20.93, median 20 and SD 2.19. In relationship domain the mean score was 10.01 , median 10 and SD 1.45. In the domain of role mean was 12.46, median 13 and SD 1.45 and in the area of change mean score was 6.73, median 7 and SD 1.52.

Section III Findings related to description of level of Self-Competency

The section described the analysis, description, and interpretation of data collected to identify the level of professional self competency by using both descriptive and inferential statistics.

Table 7 Mean, Median and Standard deviation of staff nurses overall self-competency score $n=100$

\begin{tabular}{|l|c|c|l|l|}
\hline Variable & range & Mean & Median & $\begin{array}{l}\text { Standard } \\
\text { Deviation }\end{array}$ \\
\hline $\begin{array}{l}\text { Self- } \\
\text { Competency }\end{array}$ & $8-24$ & 14.59 & 15 & 2.96 \\
\hline
\end{tabular}

Table 8 Frequency percentage distribution of staff nurses overall self-competency score $\mathbf{n}=\mathbf{1 0 0}$

\begin{tabular}{|l|c|c|c|}
\hline \multicolumn{2}{|c|}{ Level of competency } & Frequency & Percentage \\
\hline High & $>17.5$ & 21 & $21 \%$ \\
\hline Moderate & $11.6-17.5$ & 77 & $77 \%$ \\
\hline Low & $<11.6$ & 2 & $2 \%$ \\
\hline
\end{tabular}

Data presented in the table 6 depicted that most of the staff nurses were $21 \%$ had high level of self competency, $77 \%$ had moderate level of self competency and $2 \%$ had low level of self competency.

Section IV Findings related to description of relationship between the job induced stress and professional self-competency.

Table 9 Correlation coefficient between the levels of job induced stress and level of self competency. $\quad n=100$

\begin{tabular}{|l|l|l|l|l|}
\hline Variables & Mean & SD & $\begin{array}{l}\text { r } \\
\text { value }\end{array}$ & t value \\
\hline Job induced Stress & 79.88 & 4.26 & 0.706 & $9.922 * * *$ \\
\hline $\begin{array}{l}\text { Professional self- } \\
\text { competency }\end{array}$ & 14.59 & 2.96 & & \\
\hline \multicolumn{4}{|l|}{$' t$ ' $d f(99)=1.98 p<0.05,3.39 p<0.001$} \\
\hline
\end{tabular}

Data presented in the table 9 depicted there was positive correlation between the levels of job induced stress and level of self competency. It was also evident from ' $t$ ' value of 9.922 which was statistically significant at 0.001 levels. Hence it could be concluded that high selfcompetency level was related to high job induced stress level.

Section V Findings related to association between the level of job Induced Stress and selected demographic variables.

Table 10 Correlation between job induced stress and selected demographic variables namely age, job experience, and total family income. $n=100$

\begin{tabular}{|l|l|c|}
\hline Selected variables & r value & t value \\
\hline Stress vs. age & 0.146 & 1.461 \\
\hline Stress vs. job experience & -0.048 & 0.47 \\
\hline Stress vs. total family income & 0.136 & $9.92 * * *$ \\
\hline
\end{tabular}
't’ $d f(99)=1.98 p<0.05,3.39 p<0.001$

Data presented in the table 10 indicated that, $r$ value computed between job induces stress level and age was 0.146, which showed there was weak positive correlation, and ' $t$ ' value was 1.461 which was statistically not significant at 0.05 level. Hence it can be concluded that job induced stress was not dependent on age of the staff nurses.

Data also depicted that $r$ value computed between the level of job induced stress and months of job experience was 0.048 , which showed there was negative weak correlation. It was found statistically not significant as ' $t$ ' value found 0.47 . So job induced stress of newly joined staff nurses was not dependent on their job experience.

Data also indicated that $r$ value computed between level of job induced stress and total family income was 0.136 , which showed there was weak positive correlation. It was found statistically significant at 0.001 level as ' $t$ ' value 9.92. Hence it can be concluded that job induced stress was dependent on total family income of the newly joined staff nurses.

Data presented in the table 9 indicated that 12 GNM nurses scored below median level of job induced stress and 21 of them scored at above median level of job induced stress score. Similarly 16 B.Sc. Nurse scored below median level of job induced stress and 23 of them score above median level of 
job induced stress score. And 22 Post B.Sc. nurses have scored below median level of job induced stress score and 6 of them scored above median level of job induced stress score. Computed chi square test of association was found to be statistically significant as evident from chi square value of 12.85 at 0.001 level of significance. Hence it can be concluded that job induced stress was dependent on qualification of the newly joined staff nurses.

Table 11 Chi square test showing association between level of job induced stress with selected demographic variables namely qualification, place of posting, marital status, placed of living and types of family. $\mathbf{n}=\mathbf{1 0 0}$

\begin{tabular}{|c|c|c|c|c|}
\hline $\begin{array}{l}\text { Selected } \\
\text { variables }\end{array}$ & $\begin{array}{r}\text { level of jo } \\
\text { st } \\
<\text { Median }\end{array}$ & $\begin{array}{l}\text { b induced } \\
\text { ess } \\
>\text { Median }\end{array}$ & Total & $\begin{array}{l}\text { Chi- } \\
\text { square }\end{array}$ \\
\hline \multicolumn{5}{|l|}{ Qualification } \\
\hline GNM & 12 & 21 & 33 & 12.85 *** \\
\hline B.sc nursing & 16 & 23 & 39 & \\
\hline P.b.b.sc nursing & 22 & 6 & 28 & \\
\hline \multicolumn{5}{|l|}{ Place of Posting } \\
\hline Medicine & 30 & 20 & 50 & $4 *$ \\
\hline Surgery & 20 & 30 & 50 & \\
\hline \multicolumn{5}{|l|}{ Marital status } \\
\hline Married & 10 & 30 & 40 & \multirow[t]{2}{*}{$16.66^{* * * *}$} \\
\hline Unmarried & 40 & 20 & 60 & \\
\hline \multicolumn{5}{|l|}{ Place of Living } \\
\hline Home & 28 & 15 & 43 & $6.89 * *$ \\
\hline Outside home & 22 & 35 & 57 & \\
\hline \multicolumn{5}{|l|}{ Types of Family } \\
\hline Joint & 22 & 20 & 42 & 0.16 \\
\hline Nuclear & 28 & 30 & 58 & \\
\hline
\end{tabular}

Data also showed that 30 newly joined staff nurses of medicine ward scored below median level of job induced stress score and 20 of them scored above median level of job induced stress score. Similarly 20 newly joined staff nurses of Surgery ward have scored below median level and 30 have scored more than median level of job induced stress score. Computed chi square test of association was found to be statistically significant as evident from chi square value of 4 at 0.05 level of significance. So it can be concluded that job induced stress was dependent on the place of posting of the newly joined staff nurses.

Data also revealed that 30 newly joined staff nurses were married and scored below median level of job induced stress score and 10 of them scored above median level of job induced stress score. Similarly
20 newly joined unmarried staff nurses had scored below median level and 40 had scored more than median level of job induced stress score. Computed chi square test of association was found to be statistically significant as evident from chi square value of 16.66 at 0.001 level of significance. Hence it can be concluded that job induced stress was dependent on marital condition of the newly joined staff nurses.

Data reveals that 28 newly joined staff nurses were staying in home had scored below median level of job induced stress score and 15 of them scored above median level of job induced stress score. Similarly 22 newly joined staff nurses staying in outside of home have scored below median level and 35 have scored above median level of job induced stress score. Computed chi square test of association was found to be statistically significant as evident from chi square value of 6.89 at 0.01 level of significance. Hence it can be concluded that job induced stress was dependent on place of living of the newly joined staff nurses.

Data also showed that 22 newly joined staff nurses belongs to joint family had scored below median level of job induced stress score and 20 of them scored above median level of job induced stress score. Similarly 28 newly joined staff nurses belonged to nuclear family had scored below median level and 30 had scored above median level of job induced stress score. Computed chi square test of association was found to be statistically not significant as evident from chi square value of 0.16 at 0.05 level of significance. Hence it can be concluded that job induced stress was not dependent on the types of family of the newly joined staff nurses.

Section VI Findings related to association between the level of Self Competency and selected demographic variables.

This section dealt with the correlation and association between the self competency of the newly joined staff nurses with selected demographic variables. 
Riya Khanam. Assessment of job induced stress and self-competency among the newly joined staff nurses working in the selected hospital, West Bengal.

Table 12 Correlation between self competency and selected demographic variables namely age, job experience, and total family income. $n=100$

\begin{tabular}{|l|l|l|}
\hline Selected variables & r value & t value \\
\hline Self Competency vs. age & 0.105 & 1.04 \\
\hline Self Competency vs. job experience & 0.013 & 0.13 \\
\hline Self Competency vs. total family income & 0.080 & 0.79 \\
\hline
\end{tabular}

$$
\text { ' } t \text { ' } d f(99)=1.66, p<0.05
$$

Data presented in the table 10 indicated that ' $r$ ' value computed between self competency level and age was 0.105, which showed there was weak positive correlation, and ' $\mathrm{t}$ ' value was 1.04 which was statistically not significant at 0.05 level. Hence it can be concluded that self competency was not dependent on age of newly joined staff nurses.

Data also depicted that ' $r$ ' value computed between the level of self competency and months of job experience was 0.013 , which showed there was positive weak correlation. And it was found statistically not significant as ' $\mathrm{t}$ ' value found 0.13 at 0.05 level of significance. So it can be concluded that self competency was not dependent on job experiences of the newly joined staff nurses.

Data also indicated that ' $r$ ' value computed between level of self competency and total family income was 0.080, which showed there was weak positive correlation. And it was found statistically not significant as ' $t$ ' value was 0.79 at 0.05 level of significance. Hence it can be concluded that self competency was not dependent on total family income of the newly joined staff nurses.

Data presented in the table 11 indicated that, 12 GNM nurses scored below median level of self competency and 21 of them scored at above median level of self competency score. Similarly 13 B.Sc. Nurse scored below median level of self competency and 26 of them score above median level of self competency score. And 22 Post B.Sc. nurses had scored below median level of self competency score and 6 of them scored above median level of self competency score. Computed chi square test of association was found to be statistically significant as evident from chi square value of 15.62 at 0.001 level of significance.
Hence it can be concluded that self competency was dependent on qualification of newly joined staff nurses.

\begin{tabular}{|c|c|c|c|c|}
\hline $\begin{array}{l}\text { Selected } \\
\text { variables }\end{array}$ & $\begin{array}{r}\text { Self com } \\
<\text { Median }\end{array}$ & $\begin{array}{l}\text { petency } \\
\text { Median }\end{array}$ & Total & $\begin{array}{l}\text { Chi- } \\
\text { square }\end{array}$ \\
\hline \multicolumn{5}{|l|}{ Qualification } \\
\hline GNM & 12 & 21 & 33 & 15.62 **** \\
\hline B.Sc. Nursing & 13 & 26 & 39 & \\
\hline $\begin{array}{l}\text { P.B.B.Sc. } \\
\text { Nursing }\end{array}$ & 22 & 6 & 28 & \\
\hline \multicolumn{5}{|l|}{ Place of Posting } \\
\hline Medicine & 30 & 20 & 50 & $6.78 * *$ \\
\hline Surgery & 17 & 33 & 50 & \\
\hline \multicolumn{5}{|l|}{ Marital Status } \\
\hline Married & 10 & 30 & 40 & $12.93 * * *$ \\
\hline Unmarried & 37 & 23 & 60 & \\
\hline \multicolumn{5}{|l|}{ Place of Living } \\
\hline Home & 24 & 19 & 43 & 2.35 \\
\hline Outside Home & 23 & 34 & 57 & \\
\hline \multicolumn{5}{|l|}{ Types of Family } \\
\hline Joint & 13 & 29 & 42 & $7.48 * *$ \\
\hline Nuclear & 34 & 24 & 58 & \\
\hline
\end{tabular}

Data also showed that 30 newly joined staff nurses of medicine ward scored below median level of self competency score and 20 of them scored above median level of self competency score. Similarly 17 newly joined staff nurses of Surgery ward had scored below median level and 33 had scored more than median level of self competency score. Computed chi square test of association was found to be statistically significant as evident from chi square value of 6.78 at 0.01 level of significance. Hence it can be concluded that self competency was dependent on the place of posting of the newly joined staff nurses.

Data also revealed that 10 newly joined staff nurses were married and scored below median level of self competency score and 30 of them scored above median level of self competency score. Similarly 37 newly joined unmarried staff nurses had scored below median level and 23 had scored more than median level of self competency score. Computed chi square test of association was found to be statistically significant as evident from chi square value of 12.93 at 0.001 level of significance. Hence it can be concluded that self 
competency was dependent on marital condition of the newly joined staff nurses.

Data also revealed that 24 newly joined staff nurses were staying in home had scored below median level of self competency score and 19 of them scored above median level of self competency score. Similarly 23 newly joined staff nurses were staying in outside of home had scored below median level and 34 had scored above median level of self competency score. Computed chi square test of association was found to be statistically not significant as evident from chi square value of 2.35 at 0.05 level of significance. Hence it can be concluded that self competency was not dependent on place of living of the newly joined staff nurses.

Data also showed that 13 newly joined staff nurses belonged to joint family had scored below median level of self competency score and 29 of them scored above median level of self competency score. Similarly 34 newly joined staff nurses belonged to nuclear family had scored below median level of self competency score and 24 had scored above median level of self competency score. Computed chi square test of association was found to be statistically significant as evident from chi square value of 7.48 at 0.01 level of significance. Hence it can be concluded that self competency was dependent on the types of family of the newly joined staff nurses.

\section{DISCUSSION}

On the basis of the findings in the present study and objectives of the study discussion was held in relation to other studies.

\section{Findings related to sample characteristics}

The findings in the present study revealed that majority (41\%) of the newly joined staff nurses within the age group above 25 years, and all (100\%) are female nurse. Almost $(60 \%)$ are unmarried, and majority (54\%) had 4-8 months of working experience. Most (43\%) of them residence in home, and maximum (57\%) had 15000$30000 /-$ total monthly family income. Most
$(58 \%)$ of them are belongs to nuclear family. In the present study maximum (39\%) respondent were B.Sc. nurse.

The findings were consistent with previous investigation of Sharma P (2014) [7]. She was found out of 100 staff nurses majority (91\%) 23-35 years age group, most $(66 \%)$ of them are female, and most $(65 \%)$ of them unmarried.

The findings were consistent in previous investigation of Ebstein A $\mathrm{M}$ (2015) [8]. He found out of 100 oncology nurse that most $(68 \%)$ of the nurses were 20-30 years of age, majority $(95 \%)$ of the participants were female and first 3 months of joining the nurses faced occupational stress

Another study conducted by Gulavani A (2014) [9]. And she found that out of 100 nurses $54 \%$ were in age group of 21 to30 years, being female with sex $86 \%$, maximum $60 \%$ nurses were with professional education of RGNM, 51\%were having below 5 years of experience and $68 \%$ belonged nuclear family.

Findings related to the level of job induced stress among the newly joined staff nurses

The findings of the present study revealed that most $(100 \%)$ of all scored below mean average level which indicated very high risk in each area of job induced stress.

The findings were consistent with the previous investigation of Amini $\mathrm{K} \mathrm{M}$ (2017) [10]. He found that majority $(77.1 \%)$ extreme occupational stress level among the nurses and $21.7 \%$ moderate level of occupational stress.

Another study was conducted by Blomberg K (2016) [11] with 113 nurses who had recently graduated from three Swedish universities were found that the stress was high among the newly graduated nurses but it differed significantly between workplaces, surgical departments generating the most stress. 
Findings related to the level of self competency among the newly joined staff nurses

In the present study revealed that maximum $(77 \%)$ staff nurses had moderate level of self competency.

The findings were consistent with the previous investigation of Amini K M (2017) [10] with 230 nurses and found that $58.3 \%$ of the nurses had moderate professional competency and $34.3 \%$ achieved high competence professionally.

Findings related to relation between the level of job induced stress and level of self competency.

In the present study depicted that there is moderate positive correlation (0.706) between job induced stress and self competency, and it is statistically significant at 0.001 level.

Another study was conducted by Amini K M (2017) [10] with 230 nurses and the result was found that there was a significant positive correlation $(\mathrm{r}=0.153, \mathrm{P}=$ 0.020) between the clinical self competency and occupational stress.

\section{CONCLUSION}

The study is delimited to who are willing to participate in the study. It can be replicated on a large sample so that the findings can be generalized to a large population. It replicated in different setting of the state. In depth qualitative research can be employed to explore the experiences of the newly joined nurses.

\section{Acknowledgement: None}

\section{Conflict of Interest: None}

\section{Source of Funding: None}

Ethical Approval: Approved

\section{REFERENCES}

1. Alharbi H, and Alshehry A. Perceived stress and coping strategies among ICU nurses in government tertiary hospital,
Saudi Arabia: a cross-sectional study. Annals of Saudi Medicine. 2019 JanFeb; 39(1): 48-55.

2. Kim K, Bang SS. Relationship among essential fundamental nursing skill performances, stress from work, and work capability of new clinical nurses. The journal of Korean Academic. 2014.11.30; 125-127.

3. Mohamed M.G et al. The relationship between job stress and head nurses' job performance. Research Gate. December 2015; DOI: 10.21608/pssjn.2015.34443.

4. Salem A.B et al. Development of clinical nurses competency in ICU. Journal of Nursing and Health Sciences. May 2020; vol: 9(2): 17-31.

5. Adzakpah G, Alexander S. Laar, and Harrison S. Occupational Stress among Nurses in Hospital Settings. Health science journal. 2016; Vol: 21(2). Page no: $12-14$.

6. Hajbaghery A, Khamechian M, and Masoodi A N. The Nurses' perceptions of occupational stress and its influencing factors: a qualitative study. Iranian journal of nursing and midwifery research. 2012. Vol: 17(5). Page no: 352-359.

7. Sharma $P$ et al. Occupational stress among staff nurses: Controlling the risk to health. Indian Journal of Occupational and Environmental Medicine. 2014 May-Aug; 18(2): page no: 52-56.

8. Mazzella E, Ann M. The relationships among coping, occupational stress, and emotional intelligence in newly hired nurses in an oncology setting. Rutgers University Community Repository. May 2015; page no:84-86

9. Gulavani A , Shinde M. Occupational Stress and Job Satisfaction among Nurses. International Journal of Science and Research (IJSR). April 2014; volume: 3(4): page no: 733

10. Amini K M, Rezaei B, Bandboni M E. The Relationship between Clinical Competence and Occupational Stress in Iranian Clinical Nurses. Pharmacophore. December 2017; 8(6) : pages -7 . 
Riya Khanam. Assessment of job induced stress and self-competency among the newly joined staff nurses working in the selected hospital, West Bengal.

11. Blomberg $\mathrm{K}$ et al. Work Stress among Newly Graduated Nurses in Relation to Workplace and Clinical Group Supervision. Journal of nursing management. 2016 Jan; 24(1): page no: 80-7.
How to cite this article: Khanam R. Assessment of job induced stress and selfcompetency among the newly joined staff nurses working in the selected hospital, West Bengal. Int J Health Sci Res. 2021; 11(10): 99-108. DOI: https://doi.org/10. 52403/ijhsr.20211013 